\title{
Socio-Economic Factors Affecting Conservation and Sustainable Utilization of the Vegetation Resources on the Islands of Lake Ziway, South-Central Ethiopia
}

\author{
Haileab Zegeye ${ }^{1 *}$, Demel Teketay ${ }^{2}$, Ensermu Kelbessa1 \\ ${ }^{1}$ Department of Plant Biology and Biodiversity Management, College of Natural Sciences, \\ Addis Ababa University, Addis Ababa, Ethiopia \\ ${ }^{2}$ Department of Crop Science and Production, Botswana College of Agriculture, Gaborone, \\ Botswana \\ Email: " haileabzegeye@fastmail.fm
}

Received 5 September 2014; revised 12 October 2014; accepted 30 October 2014

Academic Editor: Rubén Ortega Álvarez, North American Bird Conservation Initiative-Mexico (NABCI-Mexico), Mexico

Copyright (C) 2014 by authors and Scientific Research Publishing Inc.

This work is licensed under the Creative Commons Attribution International License (CC BY).

http://creativecommons.org/licenses/by/4.0/

(c) (i) Open Access

\section{Abstract}

The study was conducted on the islands of Lake Ziway, south-central Ethiopia. The aim of the study was to investigate the socio-economic factors affecting the vegetation resources and the indigenous resource management systems and practices on the islands. Data were collected by field observations, interviews and group discussion. The island communities were engaged in diverse economic activities. The fishing industry was the main pillar of the economy as most of the income (75.7\%) was derived from this sector. The existence of diverse economic activities had relieved the pressure on the vegetation resources. The natural vegetation was the major source of fuelwood, construction material, farm implements, edible fruits, medicines, fodder and bee forage. The islanders have maintained the soil and vegetation resources for centuries through their environmental friendly resource management systems and practices. At present, however, the vegetation resources are dwindling due to free livestock grazing, farmland expansion, soil erosion and tree cutting for various purposes, all of which are driven by human population growth. Since the islanders have high respect and trust for the church, integrating environment and development issues with this institution would be more effective. The prevailing natural and anthropogenic

"Corresponding author.

How to cite this paper: Zegeye, H., Teketay, D. and Kelbessa, E. (2014) Socio-Economic Factors Affecting Conservation and Sustainable Utilization of the Vegetation Resources on the Islands of Lake Ziway, South-Central Ethiopia. Natural Resources, 5, 864-875. http://dx.doi.org/10.4236/nr.2014.514074 
factors affecting the vegetation resources on the islands necessitate effective conservation and management interventions.

\author{
Keywords
}

\author{
Conservation, Sustainable Utilization, Livelihoods, Islands of Lake Ziway, Ethiopia
}

\title{
1. Introduction
}

An island is an area of land smaller than a continent and is entirely surrounded by water. There are numerous islands in oceans, seas, lakes and rivers across the world. Isolated patches of habitats on mainlands scattered through the landscape-such as mountaintops, springs and caves-are also considered as islands, and can be studied in the same ways as oceanic islands for patterns of colonization and extinction [1]. There are two main types of islands - continental and oceanic [1].

Mainland ancestors of most species inhabiting islands were able to gain access to the islands by means of long-range dispersal [1]-[3]. Island biotas usually have taxonomic affinities with the organisms inhabiting the nearest continent or other nearby landmasses, which serve as a source of propagules. Islands have clear boundaries, are relatively ecologically simple, have already developed a balance between their size and species number, cannot be easily encroached upon, and are relatively independent ecological units [1] [4].

Generally, islands have low species richness, but there are some islands such as Madagascar, Mauritius, Galapagos and Hawaii which possess very high biodiversity and endemism [1] [3] [5]-[7]. Islands are recognized as hotspots of endemicity and evolutionary marvels [1]. The high endemism on islands can be attributed to allopatric and sympatric speciation [1] [3] [8].

However, island ecosystems are vulnerable to natural calamities such as volcanic eruptions, rising sea levels, coastal erosion, deposition, floods, hurricanes, wildfires, pests and diseases, and climate change, and a variety of anthropogenic disturbances such as habitat destruction and fragmentation, overexploitation of resources (excessive logging, overhunting, overfishing) and introduction of exotic species [1] [3] [7]-[11]. Island ecosystems are extremely fragile, and species are sensitive to extinction [5] [12]. Nowadays, there is continuing and increasing impoverishment of island biotas mainly due to increasing human impacts. Thus, islands need urgent conservation actions.

Many islands of Africa possess a unique biological diversity. Madagascar, Mauritius, Comoros, Seychelles, and São Tomé and Príncipe are important centres of endemism. Madagascar has the highest level of endemism of any country in Africa [13]. Africa's biodiversity, however, is seriously threatened not only on the mainland but also on its islands [13]. This is mainly due to increasing pressure from the rapidly growing human population.

Many islands' ecosystems are quite insufficiently studied [10]. This is mainly because of their inaccessibility. As a result, information on island biotas is very limited. This is the case of many islands in Africa. The great evolutionary, ecological and socio-economic significance of islands on the one hand and the increasing human pressure on the other necessitate greater biodiversity conservation and research.

Ethiopia has a number of lake islands. Islands with sizeable surface areas are found in lakes Tana, Ziway, Langano, Shalla, Abaya, Afrera and others. However, information on the biotas and socio-economic settings of islands in Ethiopia is very limited. Realizing such knowledge gaps, recently some studies have been undertaken, for example, by Zegeye et al. [10] on the vegetation of the islands of Lake Ziway, by Alelign et al. [14] [15] on the woody species of Zegie Peninsula of Lake Tana, and by Teklehaymanot and Giday [16] on the medicinal plants of Zegie Peninsula. The present study was, therefore, undertaken to investigate the socio-economic factors affecting the vegetation resources and the indigenous resource management systems and practices on the islands of Lake Ziway.

\section{Materials and Methods}

\subsection{Study Area}

The study was conducted on the islands of Lake Ziway, south-central Ethiopia (Figure 1). The study area lies in the Lakes Region or Main Ethiopian Rift (MER) of the Ethiopian Rift Valley (ERV), specifically at the junction 


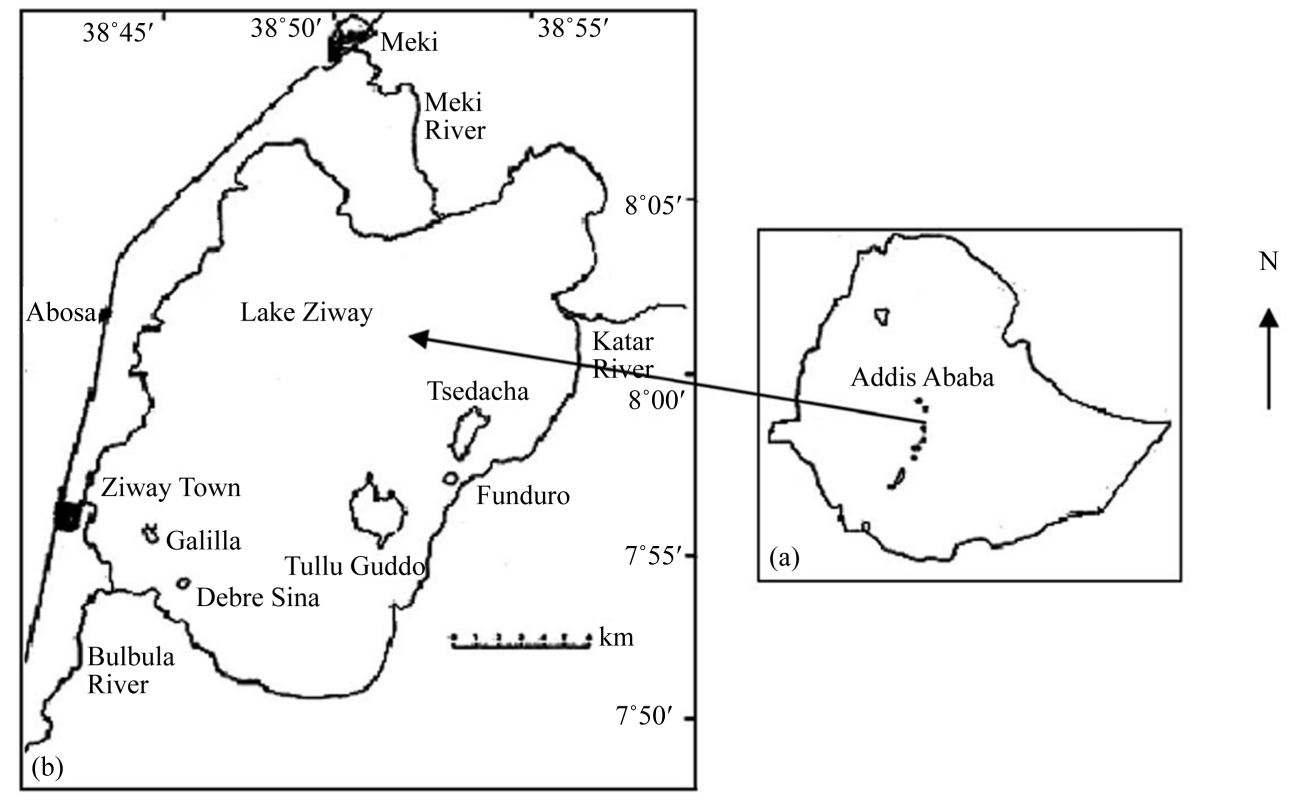

Figure 1. Map showing (a) Location of the study area (b) Lake Ziway and its islands (modified from Makin et al. [17]).

of the East Shewa Zone and Arsi Zone, within Oromia National Regional State (ONRS). Lake Ziway is located at $7^{\circ} 52^{\prime}-8^{\circ} 8^{\prime} \mathrm{N}$ and $38^{\circ} 40^{\prime}-38^{\circ} 56^{\prime} \mathrm{E}$ close to Ziway town, which is located about $160 \mathrm{~km}$ south of Addis Ababa. It lies east of Ziway town, west of Assela town, north of Mount Aluto and south of Mount Bora. There are five main volcanic islands in Lake Ziway, namely Galilla, Debre Sina, Tullu Guddo (the largest), Funduro and Tsedacha. The former two are administered by the East Shewa Zone while the latter three are administered by the Arsi Zone. The altitude of the islands ranges from $1549 \mathrm{~m}$ asl at the lake banks to $2033 \mathrm{~m}$ asl at the Tullu Guddo summit (known locally as Woizero).

The islands and immediate areas to the eastern and northeastern sides of Lake Ziway are similar in geological structure. They consist of basaltic lavas and cinder cones as well as silicic flows and domes formed during the Quaternary age as a result of fissure eruptions [18]. The rocks of the areas to the west of Lake Ziway are composed of alluvial material and lacustrine sediments. The waterbed of Lake Ziway and the swampy areas around the lake are mainly composed of coarse pumice material [17]. Most parts of the islands are covered by volcanic rocks, mainly basalt and pumice. Soils of volcanic origin, particularly ash, are common on the slopes while soils of colluvial and lacustrine origin are common along lake banks. Generally, the soils are shallow and sandy, and are characterized by low organic matter. The colour of the soils is mostly grey, whitish or brown depending on location.

The Lake Ziway area is characterized by arid climate. It has a bimodal rainfall distribution with short-term, highly variable "small" rains from February to June and "big" rains from July to September. The dry season extends from October to January. Strong and persistent winds are characteristic feature of the Lake Ziway area. Data obtained from the National Meteorological Services Agency (NMSA) for the study area showed that the mean annual temperature is $20.5^{\circ} \mathrm{C}$ and the mean annual rainfall is $702 \mathrm{~mm}$.

Open Acacia woodland is characteristic of the Rift Valley area [19]. The vegetation of the Lakes Region of the ERV varies with the climate from open Acacia woodland in the plains of the rift floor to forest areas on the escarpments. Predominant vegetation types are Acacia woodland, bushland, shrubland and wooded grassland [19] [20]. Much of the shorelines of Lake Ziway are covered with a belt of lush marshy vegetation. The islands have vegetation consisting of different trees and shrubs interspersed with climbers and herbs. Lake Ziway harbours fish, hippopotamus and Nile monitor, and is a habitat for a variety of birds. The islands are habitats for monkeys, warthog, porcupine and various kinds of birds.

The inhabitants of the islands of Lake Ziway are the Zay people. They inhabited the islands sometime between the early 14th and the middle of the 17th centuries for different reasons [21]. They speak Zayigna, which 
belongs to one of the main language groups called Semitic. The Zay people are Christians strongly dedicated to their religion. There is a church in each island. The land use systems on the islands are: cultivated land, forest land (which is also grazing land), settlement area, religious site, and fishing area or the lake. The Zay people used to inhabit all the five islands until very recently. At present, however, they live on three of the islands: Tullu Guddo, Funduro and Tsedacha. The other two islands, Galilla and Debre Sina, were abandoned mainly due to shortage of land and limited services. The economy of the Zay people is mainly based on traditional fishing and subsistence agriculture. Fishing has played a vital role not only in the subsistence economy but also in the development of the unique culture which has flourished on the islands [22].

\subsection{Methods}

Participatory Rural Appraisal (PRA) was employed to generate socio-economic data following Martin [23] and Cunningham [24]. Data were collected by field observations, interviews and group discussion. Field observations were made on land use types, extent of soil erosion and vegetation degradation, human impacts on the vegetation resources, and indigenous resource management systems and practices.

Interviews were undertaken using semi-structured/open-ended questionnaires prepared in advance. From a total of 294 households (130 in Tullu Guddo, 20 in Funduro, 144 in Tsedacha), 60 households (20\%) were randomly selected, and the household heads were interviewed. Six key informants, suggested by the local people and local representatives, were selected and interviewed informally so as to enrich the data. During the interviews with key informants, emphasis was given to issues related to the vegetation resources in order to get indepth information about the past and present status, indigenous resource management systems and practices, utilization, and major threats. Three clergymen, suggested by the local people and local representatives, were selected and interviewed. Six relevant stakeholders, namely Woreda Rural Land and Natural Resources Administration Office, Woreda Agriculture Office, Woreda Administrative Office, Woreda Church Office, Ziway Fish Production and Marketing Enterprise and Ziway Fisheries Resources Research Centre, were selected from the East Shewa Zone in Ziway town, and interviewed.

A group consisting of elderly people, youth, women, clergymen and representatives of the local communities was formed. At the beginning of the discussion, the aim of the study was explained briefly to the participants so as to ensure openness in the discussion. During the discussion, emphasis was given to the strategies needed to conserve the vegetation resources and solve the existing socio-economic problems on the islands. The ideas and suggestions forwarded by the group participants were recorded.

\subsection{Data Analysis}

Microsoft Excel software was used for analysis of the survey data, and the results of the analyses were presented using descriptive statistics.

\section{Results and Discussion}

\subsection{Household Characteristics}

The 60 households had a total of 418 members, of which $49.3 \%$ were males and $50.7 \%$ females (Table 1 ). The mean family size of the households was 7 . About $75 \%$ of the households were male-headed while $25 \%$ femaleheaded. About $67 \%$ of the household members were in the age of $\leq 20$ years, 31.1\% from $21-60$ years and $1.9 \%>60$ years (Table 1). There was high young generation, indicating that the population is growing. The human population growth has resulted in increased pressure on the natural resources in general and the vegetation resources in particular. About $37.3 \%$ of the household members were illiterate and $62.7 \%$ literate varying from primary to higher education (Table 2). Out of the total households, about $28.3 \%$ received health and family planning education.

The mean land size of the households was 0.79 ha. Out of the total households, about $33.3 \%$ had access to $\leq$ 0.5 ha, $53.3 \%$ from 0.5 - 1.0 ha, $11.7 \%$ from 1.0 - 1.5 ha and 1.7\% > 1.5 ha. About $88.3 \%$ of the households had their own land, 23.3\% rented land, 6.7\% shared cropland, and 3.3\% were landless (Table 2). Most of the land was used for crop cultivation, only a very small portion was used for fruit and vegetable production, and no land was allocated for woodlot. The shortage of land was a major problem, and led to infringing of farmlands into the natural vegetation. 
Table 1. Age and sex structure of the households.

\begin{tabular}{cccc}
\hline \multirow{2}{*}{ Age category $(\mathrm{n}=418)$} & Male & Frequency $(\%)$ & Total \\
\cline { 2 - 4 }$\leq 5$ & 10.3 & Female & 21.1 \\
$6-10$ & 11.0 & 10.8 & 20.8 \\
$11-15$ & 7.2 & 9.8 & 14.8 \\
$16-20$ & 3.8 & 7.7 & 10.3 \\
$21-60$ & 15.8 & 6.5 & 31.1 \\
$>60$ & 1.2 & 15.3 & 1.9 \\
Total & 49.3 & 0.7 & 100.0 \\
\hline
\end{tabular}

Table 2. Education, land holding and occupations of the households.

\begin{tabular}{|c|c|c|}
\hline Characteristics & Parameter & Frequency (\%) \\
\hline \multirow[t]{8}{*}{ Education } & Literacy level $(n=418)$ & \\
\hline & Cannot read and write & 34.0 \\
\hline & Can read and write & 3.3 \\
\hline & Primary school (Grades 1 - 6) & 36.6 \\
\hline & Junior secondary school (Grades 7 - 8) & 14.6 \\
\hline & High school (Grades 9 - 12) & 8.4 \\
\hline & Grade 12 complete & 2.6 \\
\hline & Higher education & 0.5 \\
\hline \multirow[t]{5}{*}{ Land holding } & Land holding type $(\mathrm{n}=60)$ & \\
\hline & Own land & 88.3 \\
\hline & Rented land & 23.3 \\
\hline & Shared cropland & 6.7 \\
\hline & Landless & 3.3 \\
\hline \multirow[t]{13}{*}{ Occupations } & Occupation type $(n=60)$ & \\
\hline & Fishing & 85.0 \\
\hline & Crop production & 80.0 \\
\hline & Livestock production & 75.0 \\
\hline & Traditional brewery & 41.7 \\
\hline & Fruit production & 31.7 \\
\hline & Weaving traditional clothes & 30.0 \\
\hline & Casual work & 30.0 \\
\hline & Handcraft & 26.7 \\
\hline & Apiculture & 21.7 \\
\hline & Vegetable production & 20.0 \\
\hline & Chat production & 11.7 \\
\hline & Trading & 5.0 \\
\hline
\end{tabular}

The occupations of the households were diverse. The major activity was fishing (85\%), followed by crop production (80\%) and livestock production (75\%) (Table 2). The households cultivated mainly cereal crops such as Eragrostis tef, Eleusine coracana and Zea mays, as well as Sorghum bicolor, Hordeum vulgare and Triticum spp. They also cultivated leguminous crops such as Phaseolus vulgaris; oil crops such as Linum usitatissimum; cash crops such as Gossypium spp., Catha edulis and Rhamnus prinoides; and fruit crops such as Citrus aurantifolia, Carica papaya and Psidium guajava. Crops were largely produced for consumption. Generally, 
homegardening was very limited. The households reared cattle (81.7\%), goats (80.0\%), sheep (33.3\%), donkeys (16.7\%) and poultry (86.7\%). The mean number of livestock per household was 13, and for cattle, goats, sheep, donkeys and poultry were 3, 5, 2, 1 and 5, respectively. The households reared both indigenous and improved varieties of poultry (about $18.3 \%$ had improved varieties). The main reasons for rearing animals were for draught power, transport, production of milk and meat for consumption, income from sale of animals and their products, as well as hide and skin for bedding and mattress. The existence of diverse economic activities had relieved the pressure on the vegetation resources.

The mean annual income and expenditure of the households were ETB 1804.27 and 1742.02, respectively. The contribution to the annual income from fish sale alone was ETB 1365.60. Thus, the fishing industry was the main pillar of the economy as most of the income $\mathbf{7 5 . 7 \% )}$ was derived from this sector. The other sources of income included sale of animals and their products, fruits, honey, handcrafts and local drinks, and casual work.

\subsection{Tree Planting}

About $52 \%$ of the households planted trees and the rest $48 \%$ didn't pant trees in the last five years preceding this study. Some exotic tree species (e.g. Eucalyptus camaldulensis, Jacaranda mimosifolia, Melia azedarach, Schinus molle, Spathodea campanulata subsp. nilotica) and indigenous tree species (e.g. Olea europaea subsp. cuspidata, Euphorbia tirucalli) were planted in homesteads, farm boundaries, roadsides and churchyards. The main reasons for planting trees were control of soil erosion, provision of wood and other products, and provision of shade and amenity. About 78.3\% of the households were willing to plant trees in the future if seedlings are supplied to them. The reasons that prevented the households from planting trees were shortage of land (10\%), have enough in the natural vegetation (6.7\%), lack of seedling supply (11.7\%), lack of awareness (5\%) and other factors like steep and rocky land (6.7\%). The percentages of the reasons that prevented the households from planting trees were relatively small. This showed that the households understood the importance of tree planting and affirmed their willingness to plant trees in the future.

However, tree planting in homesteads and other areas was very limited on the islands. Thus, there is a need to create awareness in the islanders on the importance of tree planting since it provides various products and thereby reduces the pressure on the natural vegetation. Measures have to be taken to promote planting of indigenous tree species, as well as appropriate exotic tree species. On the other hand, caution should be taken since the exotic species may become invasive and thereby affect the native flora.

\subsection{Importance of the Vegetation Resources for the Island Communities}

The island communities were highly dependent on the vegetation resources for wood and other products. The natural vegetation was the major source of fuelwood, construction material, farm implements, edible fruits, medicines, fodder and bee forage.

According to the informants, the major woody species that provide fuelwood, construction material and farm implements were Cordia africana, Ehretia cymosa, Celtis africana, Acacia tortilis, A. etbaica, Euphorbia abyssinica, E. tirucalli, Aeschynomene elaphroxylon, Maytenus senegalensis, Ziziphus mucronata and Calpurnia aurea. The informants expressed that Olea europaea subsp. cuspidata and Juniperus procera were common on the slopes of Tullu Guddo until very recently. However, selective cutting for their valuable wood has now left the trees with only very few individuals. Aeschynomene elaphroxylon and Cyperus papyrus were economically important in making local boats, which are used as the main means of water transport. All households used fuelwood for cooking, but the fuelwood consumption varied among the households. The other sources of energy for cooking were dung (15\%), crop residues (38.3\%), charcoal (36.7\%) and kerosene (21.7\%). The sources of light for the households were oil lamps (98.3\%) and "fanos" (30\%). The percentage of using charcoal for cooking was relatively high, but the households expressed that the actual consumption was very low and its use was only occasional.

The local people were found to be familiar with different edible wild plants. According to the informants, the woody species that provide edible fruits were Cordia africana, C. monoica, Pappea capensis, Lannea schimperi, Grewia bicolor, G. velutina, Rhus natalensis, Ximenia americana, Opuntia ficus-indica, Ficus sycomorus, F. ingens and F. vasta. Out of the 141 plant species identified from the islands [10], Acacia albida, A. tortilis, Acokanthera schimperi, Balanites aegyptiaca, Capparis tomentosa, Caylusea abyssinica, Celtis africana, Cleome gynandra, Coffea arabica, Commelina diffusa, Commiphora africana, Cordia africana, C. monoica, Cyperus 
esculentus, Ehretia cymosa, Erucastrum arabicum, Ficus ingens, F. sycomorus, F. thonningii, F. vasta, Flueggea virosa, Girardinia diversifolia, G. bicolor, G. velutina, Hypoestes forskaolii, Justicia schimperiana, Lannea schimperi, Maerua angolensis, M. triphylla, Olea europaea subsp. cuspidata, Pappea capensis, Pergularia daemia, Plectranthus lanuginosus, Rhamnus prinoides, Rhoicissus tridentata, Rhus natalensis, Rumex nervosus, Senna occidentalis, Urtica simensis, Ximenia americana and Ziziphus mucronata have already been reported as edible wild plants in Ethiopia [25].

The local people used wild medicinal plants to treat various human and livestock ailments. According to the informants, Solanum incanum was used against snake bite, Withania somnifera against human and livestock ailments, Cordia monoica and Heliotropium steudneri against human "Mich" (a febrile disease in which the main symptoms are fever, headache and sweating), Asparagus africanus against anthrax, and Heliotropium aegyptiacum against goat infections. Out of the plant species identified from the islands [10], Achyranthes aspera, Acokanthera schimperi, Asparagus africanus, Capparis tomentosa, Commicarpus plumbagineus, Cordia monoica, Croton macrostachyus, Heliotropium aegyptiacum, Pavetta gardeniifolia, Senna occidentalis, Solanum incanum and Withania somnifera have already been reported as medicinal plants used by the Zay people [26].

The island communities were highly dependent on the natural vegetation for livestock grazing and browsing. The animals freely graze and browse in the natural vegetation, both in the dry and wet seasons.

The natural vegetation had a high potential for beekeeping as it possessed plants that provide bee feed. According to the informants, the woody species that are of great importance in providing bee feed were Acacia tortilis, Euphorbia abyssinica, E. tirucalli, Grewia velutina, Capparis fascicularis and Aeschynomene elaphroxylon. Among the herbs, Hypoestes forskaolii was an important source of bee feed. Out of the plant species identified from the islands [10], 59 species have already been reported for their great values as bee forage [27].

\subsection{Indigenous Resource Management Systems and Practices}

The Zay people have environmental friendly resource management systems and practices. Terracing is widely practiced on the islands (Figure 2). The Zay people construct the terraces from stone, and they plant trees, particularly Euphorbia tirucalli, to give strength to the terraces. Most edges of the lake were also terraced with stone primarily to promote the growth of pasture for livestock, as well as to prevent erosion by the strong lake waves and crop damage by hippopotamus. The Zay people have an excellent practice of traditional agroforestry system (Figure 3). They retain indigenous trees like Acacia tortilis and A. albida in farmlands and farm boundaries for erosion control, improvement of soil fertility and provision of various products (fuelwood, construction material, medicines, fodder, etc.).

The Zay people also have important traditional vegetation management systems and practices, which have contributed a lot for the maintenance of the vegetation resources in the absence or very little involvement of government bodies. They construct their housewall with stone and earth. This makes the house durable and thereby reduces the turnover of cutting trees for house construction. They use dried and fallen logs for fuelwood. They do not cut trees for fuelwood but for construction material, farm implements and other purposes. They use fuelwood mostly for cooking and only rarely for lighting. They do not sell wood products but use them only for

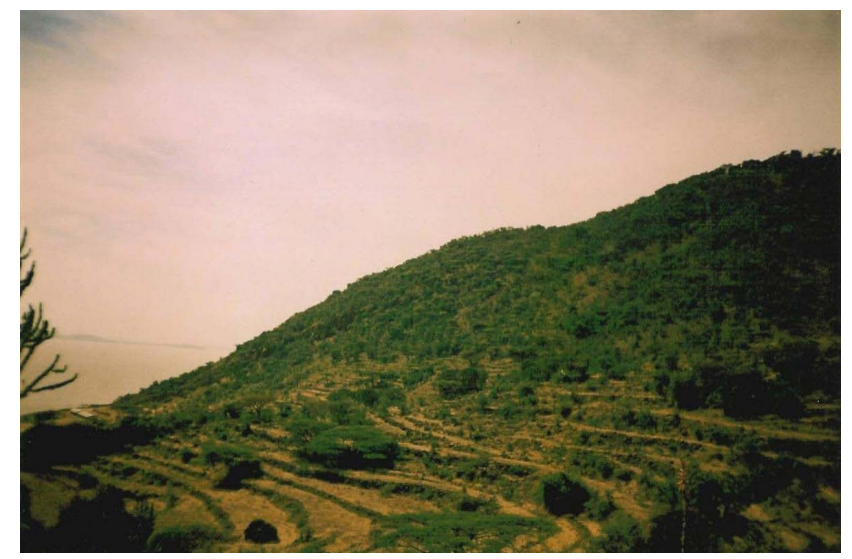

Figure 2. Terracing on the islands of Lake Ziway. 


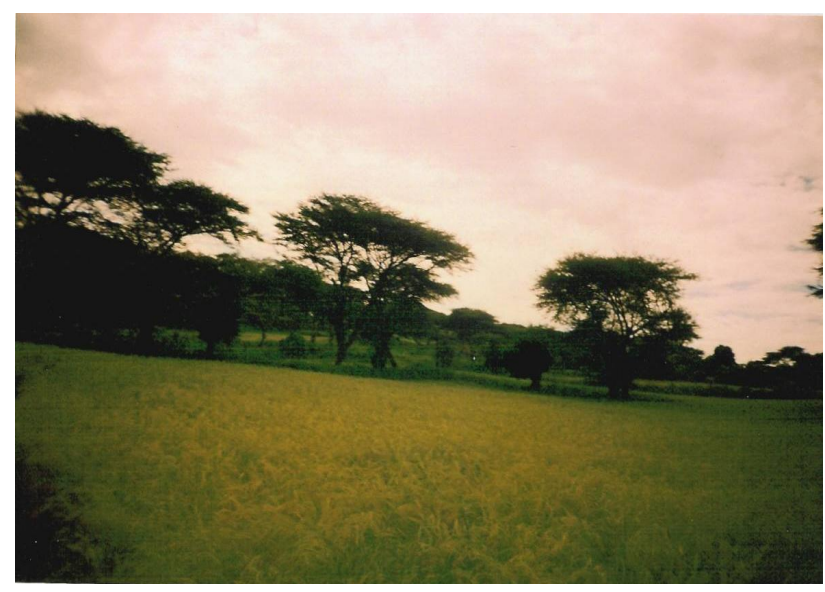

Figure 3. Traditional agroforestry on the islands of Lake Ziway.

consumption. Charcoal production was insignificant on the islands. Absence of cutting and use of trees for sale is partly a reflection of low pressure on the natural vegetation.

These peculiar knowledge systems and practices have contributed a lot for the maintenance of the soil and vegetation resources on the islands for centuries. This can help the islands to remain unique areas in the region with their beautiful environment and cultural heritage. In the mainland areas surrounding the lake, in contrast, there is pronounced deforestation and soil erosion due to farmland expansion, overgrazing, urbanization, forest fires, and tree cutting for fuelwood, construction material, timber and charcoal (field observations; local people, personal communication).

The indigenous resource management systems and practices used by the Zay people are exemplary. Zegeye et $a l$. [10] noted that they deserve special attention for scaling up to other rural areas since they have the potential to promote the conservation of biodiversity. Therefore, they supplement our knowledge on indigenous resource management systems and practices that exist in the country, such as soil and water management practices in Konso, resource management in Borana, traditional agroforestry practices in the south and southwest, and house construction with stone and earth in Tigray.

\subsection{Threats to the Vegetation Resources}

Galilla and Debre Sina had dense vegetation owing to the absence of settlement and thereby low human pressure. Tullu Guddo also had dense vegetation on the slopes, hills and rocky lake banks though lower flat areas were under settlement and cultivation. The vegetation in Funduro was slightly disturbed while the vegetation in Tsedacha was heavily disturbed due to the high population and suitability of the land for cultivation. At present, the vegetation resources on the islands are dwindling due to free livestock grazing, farmland expansion, soil erosion and tree cutting for various purposes, all of which are driven by human population growth.

According to the informants, soil erosion was insignificant on the islands until very recently because of the presence of well established terraces. At present, however, erosion has become a major problem due to damage on the terraces by livestock, particularly goats, and lack of maintenance. Rills started to form in some places, particularly on the slopes of Tullu Guddo. As a result of erosion, some individuals of trees became dry or uprooted, and rolling stones caused considerable damage on the natural vegetation. Thus, the terraces require maintenance in order to control soil erosion and thereby enhance vegetation development. Prevention of soil erosion is the priority action since the islands generally have slopy land. The damage caused by goats on the terraces and natural regeneration of trees needs special attention. As mentioned previously, the number of goats per household was high, indicating that it is a major threat to the vegetation resources.

There were livestock left to graze on their own in Galilla and Debre Sina, and also there was entry of goats by native inhabitants of the islands currently living in the shore areas. Thus, removal of livestock from the uninhabited islands and prevention of further entry are urgent actions. It is also advisable to limit the number of goats per household in the inhabited islands through provision of viable economic alternatives to the islanders.

Natural and anthropogenic disturbances have led to loss or degradation of the vegetation resources on the isl- 
ands. Rare and environmentally and economically important plant species can be lost by human activities. This will lead to serious environmental, social, economic and cultural problems on the islands unless appropriate and immediate measures are taken.

\subsection{Christianity and Vegetation Conservation}

Christianity is deep rooted in the islanders. Theft is a taboo. This was reflected by the fact that they leave their properties anywhere as deemed necessary and they don't usually close their doors. Cutting trees from the sacred groves is also a taboo. This tradition has contributed to the maintenance of the sacred groves in particular and the vegetation resources on the islands in general. Moreover, as we have already reported [10], the church has been involved in protecting the sacred groves, planting trees in churchyards and giving advice to the island communities on the importance of conserving the vegetation resources on the islands.

Trees such as Acacia tortilis, Euphorbia abyssinica, E. tirucalli, Opuntia ficus-indica, Cordia monoica, Pappea capensis and Ficus vasta were retained in churchyards and also trees like Melia azedarach were planted. Sacred groves provide various goods and services such as erosion control, protection of the church from strong winds, live fence, shade, construction material, edible fruits, medicines and plant material for religious purposes.

The recommendations forwarded by the clergymen for conservation, management and sustainable use of the vegetation resources on the islands were formation of control and management units, supply of seedlings and support from the government. From the survey it was found that the church, which is considered the house of God, has played a vital role in environment and development issues besides its religious service.

\subsection{Activities of Stakeholders}

The survey showed that the involvement of stakeholders and their contributions in conservation and development activities on the islands was very limited (Table 3). Furthermore, the integration among the stakeholders involved was very poor. Limited involvement of stakeholders and poor integration will have negative impacts on conservation and development activities that can be carried out on the islands. In order to ensure the maintenance of the vegetation resources and bring socio-economic development on the islands, there is a need to promote the involvement of all relevant stakeholders with proper integration.

\section{Conclusions and Recommendations}

The islands of Lake Ziway are characterized by rich biodiversity and cultural heritage. This has resulted from

Table 3. Major activities of stakeholders and recommendations forwarded for conservation and socio-economic development on the islands.

\begin{tabular}{|c|c|}
\hline Major activities & Recommendations \\
\hline Transport and market system ${ }^{5}$ & Proper fisheries management ${ }^{2,5,6}$ \\
\hline Provision of fishing equipment ${ }^{2,5,6}$ & Maintenance of the terraces ${ }^{1}$ \\
\hline Control of fishing activity ${ }^{2}$ & Promoting fruit production and beekeeping ${ }^{1}$ \\
\hline Control of lake pollution ${ }^{2}$ & Supply of seedlings or establishment of nurseries and promoting tree planting \\
\hline Research on fisheries resources ${ }^{6}$ & Provision of alternative sources of energy ${ }^{1}$ \\
\hline Training on fishing ${ }^{2,6}$ & Introducing irrigation system ${ }^{1,2}$ \\
\hline Protection of vegetation ${ }^{1,4}$ & Training and education ${ }^{1,2}$ \\
\hline \multirow[t]{6}{*}{ Awareness creation ${ }^{1,2,4,5,6}$} & Technical support ${ }^{1}$ \\
\hline & Designating the islands as nature reserves ${ }^{1}$ \\
\hline & Development of ecotourism ${ }^{1}$ \\
\hline & Allocation of trained manpower and budget ${ }^{1,2}$ \\
\hline & Involvement of different stakeholders ${ }^{1,2,3}$ \\
\hline & Support from the government ${ }^{1,2}$ \\
\hline
\end{tabular}

1 = Woreda Rural Land and Natural Resources Administration Office; 2 = Woreda Agriculture Office; 3 = Woreda Administrative Office; 4 = Woreda Church Office; 5 = Ziway Fish Production and Marketing Enterprise; 6 = Ziway Fisheries Resources Research Centre. 
environmental heterogeneity and unique human-environment interactions on the islands for centuries. Thus, the islands are of great environmental, social, economic and cultural significance.

The island communities were engaged in diverse economic activities. The fishing industry was the main pillar of the economy as most of the income (75.7\%) was derived from this sector. The existence of diverse economic activities had relieved the pressure on the vegetation resources.

The islanders practiced traditional beekeeping, which was carried out entirely in the natural vegetation. However, beekeeping has a high potential for income generation for the islanders. The availability of water (the lake) and presence of plants that provide bee forage make the islands suitable for beekeeping. Thus, there is a need to introduce modern beekeeping through provision of beehives, training and technical assistance so as to enhance the contribution of the sector for income generation and sustainable utilization of the vegetation resources. Moreover, the islands are sites of beautiful environment and cultural heritage, and thus are ideal places for development of ecotourism. However, this potential economic alternative has not been given due attention.

Livelihoods of island communities are affected by a number of constraints such as acute shortage of land; lack of clean water supply, modern health service, transport and attractive market system; administrative problems; and low concern from the government. Efforts that can be made to solve the prevailing socio-economic problems would help to ensure the existence of the island communities with their unique culture and this, in turn, contributes, in one way or another, to the maintenance of the vegetation resources.

The natural vegetation was the major source of fuelwood, construction material, farm implements, edible fruits, medicines, fodder and bee forage. The islanders have maintained the soil and vegetation resources for centuries through their environmental friendly resource management systems and practices. At present, however, the vegetation resources are dwindling due to free livestock grazing, farmland expansion, soil erosion and tree cutting for various purposes, all of which are driven by human population growth. Rare and environmentally and economically important plant species can be lost by human activities. This will lead to serious environmental, social, economic and cultural problems on the islands unless appropriate and immediate measures are taken.

Awareness and positive attitude of the island communities toward family planning, basic education, diverse livelihood strategies, existence of environmental friendly resource management systems and practices, absence of wood selling and efforts in tree planting are promising options for the conservation and sustainable use of the vegetation resources on the islands. Besides its religious service, the church has played a vital role in environment and development issues. Since the islanders have high respect and trust for the church, integrating environment and development issues with this institution would be more effective. The prevailing natural and anthropogenic factors affecting the vegetation resources on the islands necessitate effective conservation and management interventions.

Therefore, in order to ensure the conservation, management and sustainable utilization of the vegetation resources and improve the livelihoods of the island communities, the following recommendations are suggested:

- Curb human population growth by strengthening family planning;

- Introduce modern agricultural technologies including irrigation system;

- Promote the maintenance of the terraces;

- Promote tree planting in homesteads, farmlands, farm boundaries, woodlots, roadsides, churchyards and lake banks;

- Limit the number of goats per household through provision of viable economic alternatives to the islanders;

- Provide alternative sources of energy;

- Promote fruit and vegetable production, apiculture and poultry;

- Implement proper fisheries management;

- Provide training, technical assistance and extension services;

- Provide clean water supply, modern health service, transport and attractive market system;

- Promote the involvement of all relevant stakeholders with proper integration;

- Ensure strong support from the government;

- Develop ecotourism;

- Integrate environment and development issues with the church.

\section{Acknowledgements}

The financial support provided by SIDA-SAREC through the Ethiopian Science and Technology Commission for conducting the research is gratefully acknowledged. We are grateful to Ziway Fish Production and Market- 
ing Enterprise for facilitating boating to and from the islands. We thank our field assistants Tekle Sime and his brothers Degu Sime and Abiyot Sime for their help in data collection and local language translation, and their family in Tullu Guddo Island for sincere hospitality. We express our deepest gratitude to all informants for sharing their rich indigenous knowledge, and their cooperation during the fieldwork. The anonymous reviewers are greatly acknowledged for their valuable comments.

\section{References}

[1] Lomolino, M.V., Riddle, B.R. and Brown, J.H. (2006) Biogeography. 3rd Edition, Sinauer Associates, Inc., Sunderland.

[2] Kellman, M.C. (1980) Plant Geography. 2nd Edition, Methuen, London.

[3] Lomolino, M.V. and Heaney, L.R., Eds. (2004) Frontiers of Biogeography: New Directions in the Geography of Nature. Sinauer Associates, Inc., Sunderland.

[4] IUCN/UNEP (1986) Managing Protected Areas in the Tropics. IUCN, Gland, Switzerland.

[5] Cook, J.A. and MacDonald, S.O. (2001) Should Endemism Be a Focus of Conservation Efforts along the North Pacific Coast of North America? Biological Conservation, 97, 207-213. http://dx.doi.org/10.1016/S0006-3207(00)00113-0

[6] Johnson, G.B. (2006) The Living World. 4th Edition, McGraw-Hill Higher Education, Boston.

[7] Ricklefs, R.E. (2007) The Economy of Nature. 5th Edition, W.H. Freeman and Company, New York.

[8] Blondel, J., Aronson, J., Bodiou, J-Y. and Boeuf, G. (2010) The Mediterranean Region: Biological Diversity in Space and Time. 2nd Edition, Oxford University Press, New York.

[9] Ricklefs, R.E. and Miller, G.L. (2000) Ecology. 4th Edition, W.H. Freeman, New York.

[10] Zegeye, H., Teketay, D. and Kelbessa, E. (2006) Diversity, Regeneration Status and Socio-Economic Importance of the Vegetation in the Islands of Lake Ziway, South-Central Ethiopia. Flora: Morphology, Distribution, Functional Ecology of Plants, 201, 483-498. http://dx.doi.org/10.1016/j.flora.2005.10.006

[11] Stern, N. (2006) Stern Review: The Economics of Climate Change. Cambridge University Press, Cambridge.

[12] Cook, J.A., Bidlack, A.L., Conroy, C.J., Demboski, R.J., Fleming, M.A., Runk, A.M., Stone, K.D. and MacDonald, S.O. (2001) A Phylogeographic Perspective on Endemism in the Alexander Archipelago of Southeast Alaska. Biological Conservation, 97, 215-227. http://dx.doi.org/10.1016/S0006-3207(00)00114-2

[13] IUCN (1990) Biodiversity in Sub-Saharan Africa and Its Islands: Conservation, Management and Sustainable Utilization. Occasional Papers of the IUCN Species Survival Commission No. 6. IUCN, Gland, Switzerland.

[14] Alelign, A., Teketay, D., Yemshaw, Y. and Edwards, S. (2007) Diversity and Status of Regeneration of Woody Plants on the Peninsula of Zegie, Northwestern Ethiopia. Tropical Ecology, 48, 37-49.

[15] Alelign, A., Yemshaw, Y., Teketay, D. and Edwards, S. (2011) Socio-Economic Factors Affecting Sustainable Utilization of Woody Species in Zegie Peninsula, Northwestern Ethiopia. Tropical Ecology, 52, 13-24.

[16] Teklehaymanot, T. and Giday, M. (2007). Ethnobotanical Study of Medicinal Plants Used by People in Zegie Peninsula, Northwestern Ethiopia. Journal of Ethnobiology and Ethnomedicine, 3, 12. http://dx.doi.org/10.1186/1746-4269-3-12

[17] Makin, M.J., Kingham, T.J., Waddams, A.E., Birchall, C.J. and Evis, B.W. (1976) Land Resources Study: 26. Prospects for Irrigation Development around Lake Zwai, Ethiopia. Land Resources Division, Ministry of Overseas Development, England.

[18] Street, F.A. (1979) Late Quaternary Lakes in the Ziway-Shalla Basin, Southern Ethiopia. Ph.D. Thesis, Cambridge University, Cambridge.

[19] Woldu, Z. and Tadesse, M. (1990) The Status of the Vegetation in the Lakes Region of the Rift Valley of Ethiopia and the Possibilities of Its Recovery. SINET: Ethiopian Journal of Science, 13, 97-120.

[20] Friis, I. (1992) Forests and Forest Trees of Northeast and Tropical Africa: Their Natural Habitats and Distribution Patterns in Ethiopia, Djibouti and Somalia. Kew Bulletin Additional Series XV: 1-396. HMSO, London.

[21] Nadamo, T. (1982) A History of the Zay in the 19th and Early 20th Centuries. BA Thesis, Addis Ababa University, Addis Ababa.

[22] Edetto, T. (1988) Socio-Economic Life of the Zay with Special Emphasis on the Fishing Industry. BA Thesis, Addis Ababa University, Addis Ababa.

[23] Martin, G.J. (1995) Ethnobotany: A Methods Manual. Chapman and Hall, London. http://dx.doi.org/10.1007/978-1-4615-2496-0 
[24] Cunningham, A.B. (2001) Applied Ethnobotany: People, Wild Plant Use and Conservation. Earthscan, London.

[25] Teketay, D., Senbeta, F., Maclachlan, M., Bekele, M. and Barklund, P. (2010) Edible Wild Plants in Ethiopia. Addis Ababa University Press, Addis Ababa.

[26] Giday, M. (1999) An Ethnobotanical Study of Medicinal Plants Used by the Zay People in Ethiopia. M.Sc. Thesis, Swedish Biodiversity Centre, Uppsala.

[27] Fichtl, R. and Adi, A. (1994) Honeybee Flora of Ethiopia. Margraf Verlag, Weikersheim. 
Scientific Research Publishing (SCIRP) is one of the largest Open Access journal publishers. It is currently publishing more than 200 open access, online, peer-reviewed journals covering a wide range of academic disciplines. SCIRP serves the worldwide academic communities and contributes to the progress and application of science with its publication.

Other selected journals from SCIRP are listed as below. Submit your manuscript to us via either submit@scirp.org or Online Submission Portal.
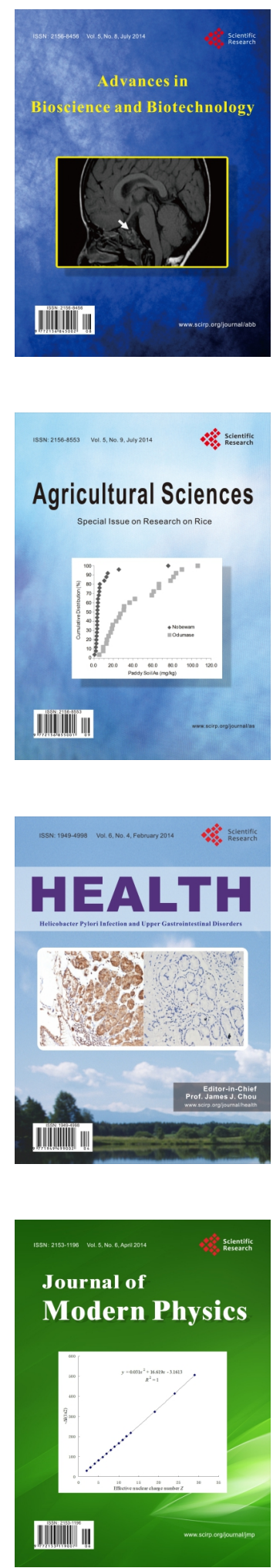
